Studia Theologica Varsaviensia

UKSW

$1 / 2021$

Ks. DR BARTOSZ TROJANOWSKI ${ }^{1}$

ORCID 0000-0003-0158-1647

\title{
WPROWADZENIE ZASTĘPCZYCH (SUBSTYTUTÓW) RODZICÓW CHRZESTNYCH PRZEZ KONFERENCJĘ EPISKOPATU POLSKI A MOŻLIWE SYTUACJE ANALOGICZNE POZA PRZYPADKAMI PRZYSPOSOBIENIA
}

\section{WSTEP}

Konferencja Episkopatu Polski w dekrecie ogólnym z 14 marca 2017 r. wprowadziła zasady sporządzania i modyfikacji aktu chrztu w związku z przysposobieniem. Określenie tych zasad wymagane jest przez Prawodawcę powszechnego w kan. 877 § 3 KPK, dlatego prawo partykularne ustanawiane przez Konferencję Episkopatu Polski na mocy kan. $455 \mathrm{KPK}$ w formie dekretu ogólnego określa te zasady w celu umożliwienia zmodyfikowania lub nawet sporządzenia nowego aktu chrztu, nawet jeśli dziecko wcześniej było ochrzczone.

Co więcej, dekret ogólny z 2017 r. wprowadza możliwość ustanowienia nowych rodziców chrzestnych, zwanych zastępczymi rodzicami chrzestnymi lub substytutami rodziców chrzestnych.

1 Ks. dr Bartosz Trojanowski jest absolwentem Papieskiego Uniwersytetu Santa Croce w Rzymie - teologia dogmatyczna oraz Papieskiego Uniwersytetu Gregoriańskiego w Rzymie - prawo kanoniczne. Adres do korespondencji: Plac Katedralny 14, 50-329 Wrocław, e-mail: b.trojanowski@hadak.pl 
Fr Bartosz Trojanowshi, PhD ${ }^{1}$

\section{INTRODUCTION OF FOSTER SPONSORS (GODPARENTS) BY THE POLISH BISHOPS' CONFERENCE VS. SIMILAR CASES EXCEPT ADOPTION}

\section{INTRODUCTION}

In its General Decree of 14 March 2017, the Polish Bishops' Conference introduced the rules for drawing up and modifying the baptismal act due to adoption. The definition of these rules is required by the universal Legislator in Can. $877 \S 3$ of the Code of Canon Law (abbreviated 1983 CIC from its Latin title Codex Iuris Canonici), therefore the particularistic law established by the Polish Bishops' Conference under can. 455 of the Code of Canon Law in the form of a general decree defines these rules in order to provide for the possibility of modifying or even drawing up a new baptismal act, even if the child was previously baptised.

Furthermore, the 2017 General Decree introduces the possibility of appointing new sponsors, known as foster godparents or substitute

1 Fr Dr Bartosz Trojanowski, PhD, is a graduate of the Pontifical University of Santa Croce in Rome - Dogmatic Theology and the Pontifical Gregorian University in Rome - Canon Law. Address for correspondence: Plac Katedralny 14, 50-329 Wrocław, e-mail: b.trojanowski@hadak.pl 
W związku z takimi postanowieniami w przypadku przysposobienia można per analogiam zauważyć inne sytuacje, w których uzasadnione byłoby wyznaczenie czy ustanowienie nowych rodziców chrzestnych również poza przypadkami przysposobienia. Jeśli stwierdzić, że bezpośrednio w prawie powszechnym taka możliwość nie istnieje, to również można uznać, iż taka podstawa prawna w prawie partykularnym w Polsce także nie istniała. Jednak w momencie, w którym dekret ogólny z 2017 r. zaczął obowiązywać, można upatrywać się pewnych podstaw do takich działań.

Celem tego artykułu będzie zatem przedstawienie analogicznych sytuacji ustanowienia zastępczych rodziców chrzestnych poza przypadkami przysposobienia oraz wykazanie podstaw prawnych do możliwości takiego postępowania na podstawie prawa partykularnego obowiązującego w Polsce.

\section{ANALOGIA FUNKCJI CHRZESTNEGO DO URZEDU KOŚCIELNEGO}

Kodeks Prawa Kanonicznego nakłada swoistego rodzaju obowiązek posiadania chrzestnego: ,przyjmujący chrzest powinien mieć, jeśli to możliwe, chrzestnego. Ma on dorosłemu towarzyszyć w chrześcijańskim wtajemniczeniu, a dziecko wraz z rodzicami przedstawić do chrztu oraz pomagać, żeby ochrzczony prowadził życie chrześcijańskie odpowiadające przyjętemu sakramentowi i wypełniał wiernie złączone z nim obowiązki” (kan. 872 KPK). Wprowadzenie takiego obowiązku należy rozumieć przez użycie słowa „powinien”, które w języku kanonicznym, jak również w języku prawniczym szerzej rozumianym, należy rozumieć jako obowiązek, który trzeba wypełnić. Z tym że, w przypadku omawianego kanonu, należy również wziąć pod uwagę klauzulę warunkującą: ,jeśli to możliwe". Oznacza to, że Prawodawca nie stawia tego obowiązku ponad prawo do sakramentu, który jest konieczny do zbawienia (por. kan. 849 KPK). Można jednak stwierdzić, że prawo kanoniczne zakłada takie sytuacje, w których nie będzie możliwe wyznaczenie chrzestnego, np. w niebezpieczeństwie śmierci czy też innej sytuacji 
godparents. In connection with such provisions in the case of adoption, per analogiam it is possible to notice other situations in which it would be legitimate to appoint or set up new sponsors apart from cases of adoption as well. If one concludes that directly in common law such a possibility does not exist, one can also conclude that such a legal basis in particularistic law in Poland did not exist either. However, when the 2017 General Decree came into force, some grounds for such action can be observed.

The purpose of this article will therefore be to present analogous situations of the appointment of foster godparents apart from cases of adoption and to demonstrate the legal basis for the possibility of such a procedure under the particularistic law in force in Poland.

\section{ANALOGY OF THE FUNCTION OF A SPONSOR TO AN ECCLESIASTICAL OFFICE}

The Code of Canon Law imposes a kind of obligation to have a sponsor. It says "Insofar as possible, a person to be baptized is to be given a sponsor who assists an adult in Christian initiation or together with the parents presents an infant for baptism. A sponsor also helps the baptized person to lead a Christian life in keeping with baptism and to fulfil faithfully the obligations inherent in it." (Can. 872). The introduction of such an obligation needs to be understood through the use of the word "should", which in the canonical language, as well as in the broader legal language, should be understood as an obligation to be fulfilled. Except that, in the case of the canon in question, the conditioning clause must also be taken into account, namely: "insofar as possible". This means that the Legislator does not place this obligation above the right to the sacrament, which is necessary for salvation (cf. Can. 849). However, it can be stated that canon law presupposes such situations in which it will not be possible to appoint a sponsor, e.g. in danger of death or another situation described as "in case of urgent necessity" (Can. 850). Unless at least one sponsor is present, it should be ensured that there is at least one witness (cf. Can. 875). 
określanej jako: „przypadki naglącej koniczności” (kan. 850 KPK). W przypadku braku przynajmniej jednego chrzestnego należałoby zatroszczyć się, aby był przynajmniej jeden świadek (por. kan. 875 $\mathrm{KPK}$ ).

A zatem norma, która wymaga przynajmniej jednego chrzestnego (por. kan. $873 \mathrm{KPK}$ ) wskazuje, że chrzestny to jednak ktoś więcej niż świadek chrztu (por. kan. 872 KPK). Już od starożytności chrześcijańskiej istniała figura chrzestnego w liturgii sakramentu chrztu. Miał on też zadania w życiu chrześcijańskim nowo ochrzczonego. O zobowiązaniach chrzestnego wspomina Tertulian, w Traktacie o chrzcie $s ́$ w. z przełomu II i III wieku². Prawdopodobnie rola chrzestnych wynikała przede wszystkim z praktycznych powodów, a mianowicie od początków Kościoła, kiedy poganin lub Żyd chciał przyjąć wiarę katolicką to wtedy byli oni przedstawiani prezbiterowi przez znanego chrześcijanina, który zaświadczał o ich odpowiedniej dyspozycji do przyjęcia sakramentu chrztu św., co szczególnie nabierało znaczenia w okresie prześladowań ${ }^{3}$. O roli chrześcijanina jako adductor lub fidedictor wspominają już starożytne źródła chrześcijańskie ${ }^{4}$.

Chociaż Prawodawca określa rolę chrzestnego jako zadanie (łac. munus), a nie urząd (łac. officium), to jednak można zauważyć pewne

2 Tertullian, De baptismo, (XVIII,4), w: Tertullien, Traité du baptême, Sources Chrétiennes, Paryż 1952, 92.

${ }^{3}$ Por. M. Blanco, „can. 872”, w: Exegetical commentary on the Code of canon law, vol. III/1, Chicago 2004, 479.

4 Tradycja apostolska: «Kiedy zostaną wyznaczeni mający zamiar przyjąć chrzest, należy sprawdzić ich życie: czy żyli godnie dopóki byli katechumenami, czy poważali wdowy, nawiedzali chorych, czynili dobre uczynki. Kiedy ci, którzy ich przyprowadzili zaświadczą o każdym: „On postępował właśnie tak”, to niech słuchają Ewangelii» (Hipolit Rzymski, Tradycja Apostolska, w: H. Paprocki, «Hipolita Rzymskiego Tradycja Apostolska. Wstęp, przekład komentarz», Studia Theol. Vars., 14/1 (1976) 158 oraz Konstytucje Apostolskie: «[Dopuszczenie do katechumenatu] Tych, którzy po raz pierwszy przystępują do tajemnicy pobożności, diakoni powinni przedstawić biskupowi lub prezbiterom; kandydatów należy zapytać, dlaczego chcą przyłączyć się do Słowa Pańskiego; ci zaś, którzy ich wprowadzają, powinni poręczyć za nich po uprzednim dokładnym ich sprawdzeniu (...)» (Konstytucje Apostolskie, A. Baron; H. Pietras (red.), Kraków 2007). 
Thus, the norm which requires at least one sponsor (cf. Can. 873) indicates that the sponsor is, however, someone more than a witness to baptism (cf. Can. 872). As early as Christian antiquity there was a figure of the godfather in the liturgy of the sacrament of baptism. He also had assignments in the Christian life of the newly baptised. The obligations of the sponsor are mentioned by Tertullian in his Treatise on Baptism from the turn of the 2 nd and 3 rd centuries ${ }^{2}$. It is likely that the role of godparents was due primarily to practical reasons, namely, from the early days of the Church, when a pagan or Jew wished to embrace the Catholic faith they were then presented to the presbyter by a known Christian who attested to their suitable disposition to receive the sacrament of baptism, which was particularly important during the period of persecution ${ }^{3}$. The role of the Christian as adductor or fidedictor is already mentioned in ancient Christian sources ${ }^{4}$.

Although the Legislator defines the role of a sponsor as an assignment (Latin: munus) and not an office (Latin: officium), one may notice certain similarities between the ecclesiastical office and the obligations of a sponsor (cf. Cann. 145, 872-874). It can be stated that the baptismal assignment fulfils all the characteristics

2 Tertullian, De baptismo, (XVIII,4), in: Tertullien, Traité du baptême, Sources Chrétiennes, Paris 1952, 92.

3 See M. Blanco, „can. 872”, in: Exegetical commentary on the Code of canon law, vol. III/1, Chicago 2004, 479.

${ }^{4}$ Apostolic Tradition: „When those who are to be baptized are appointed, their lives should be examined: whether they have lived worthily while they were catechumens, whether they have respected widows, visited the sick, done good works. When those who brought them testify of each one: ,'He acted just so,' then let them hear the Gospel" (Hippolytus of Rome, Apostolic Tradition, in H. Paprocki, "The Apostolic Tradition of Hippolytus of Rome. Introduction, Translation and Commentary", Studia Theol. Vars., 14/1 (1976) 158 and the Apostolic Constitutions: „,Admission to the catechumenate] Those who enter the mystery of piety for the first time should be introduced by the deacons to the bishop or presbyters; the candidates should be asked why they wish to join the Word of the Lord; and those who introduce them should vouch for them after having carefully examined them ..." (Apostolic Constitutions, A. Baron; H. Pietras (eds.), Krakow 2007). 
podobieństwa pomiędzy urzędem kościelnym, a zadaniem chrzestnego (por. kan. 145, 872-874 KPK). Można stwierdzić, że zadanie chrzestnego wypełnia wszystkie znamiona urzędu kościelnego. A mianowicie, zadanie chrzestnego nie jest ustalane na jakiś czas określony, nawet w przypadku dorosłego katechumena nie ogranicza się tylko do zadania podczas obrzędów wtajemniczenia, ale również ma za zadanie pomagać, ,żeby ochrzczony prowadził życie chrześcijańskie odpowiadające przyjętemu sakramentowi i wypełniał wiernie złączone z nim obowiązki” (kan. 872 KPK). I chociaż zadanie chrzestnego różni się stosownie do tego czy kandydatem do chrztu jest dorosły czy dziecko, to jednak jest to związane bardziej z przygotowaniem do samego sakramentu i sposobem uczestniczenia w liturgicznym obrzędzie. Natomiast po chrzcie zadaniem chrzestnego jest troska o życie chrześcijańskie u chrześniaka ${ }^{5}$. Można stwierdzić, że jest to zadanie obecnie wynikające z postanowienia Prawodawcy kościelnego i chociaż jego tradycja sięga starożytności chrześcijańskiej, to jednak jest wynikiem praktyki kościelnej i ustanowienia ludzkiego. Można jednak zauważyć, że jest to również przymiot wynikający z definicji urzędu kościelnego. Podobnie jak cel duchowy, dla którego realizacji ustanawiany jest dany urząd kościelny (por. kan. $145 \mathrm{KPK}$ ). W ten sposób można stwierdzić, że wszystkie cechy urzędu są zrealizowane przez zadanie chrzestnego, a co więcej w elementach konstytutywnych urzędu kościelnego Prawodawca określa je jako: ,ustanowione na stałe zadanie" (łac. munus stabiliter constitutum). Podobnie obowiązki i prawa dla zadań chrzestnego są określone samym prawem (por. kan. 872-874 KPK). Należy jednak stwierdzić, że w praktyce ani zatwierdzenie rodziców chrzestnych nie dokonuje się za pomocą dekretu kompetentnej władzy (por. kan. $145 \S 2 \mathrm{KPK}$ ), ani też nie można mówić o utracie tego zadania, nawet w przypadku nieodpowiedniego wypełniania tego zadania (por. kan. $184 \S 1 \mathrm{KPK})$. To jeden $\mathrm{z}$ decydujących aspektów, który nie pozwala

5 Por. T. Rincón-Pérez, La liturgia e i sacramenti nel diritto della chiesa, Roma 2014, 176-177. 
of the ecclesiastical office. Namely, the baptismal assignment of the sponsor is not fixed for a definite period of time, even in the case of an adult catechumen it is not limited only to the assignment during the initiation rites, but it is also to help "the baptized person to lead a Christian life in keeping with baptism and to fulfil faithfully the obligations inherent in it". (Can. 872). And although the baptismal assignment differs according to whether the candidate for baptism is an adult or a child, it is more related to the preparation for the sacrament itself and the manner of participation in the liturgical rite. After baptism the assignment of the sponsor is to care for the Christian life of the child..$^{5}$ It may be said that it is an assignment now arising from the provision of the ecclesiastical Legislature, and although its tradition goes back to Christian antiquity, it results from ecclesiastical practice and human establishment. It may be noted, however, that it is also an attribute stemming from the definition of the ecclesiastical office. So is the spiritual purpose for the realization of which a given ecclesiastical office is established (cf. Can. 145). Thus, it can be concluded that all the attributes of the office are realised in the baptismal assignment and, indeed, in the constitutive elements of the ecclesiastical office, the Legislator defines it as ,, a permanently established assignment" (Latin: munus stabiliter constitutum). Similarly, the obligations and rights for the baptismal assignments are defined by the law itself (cf. Cann. 872-874). However, it must be stated that in practice neither the approval of the godparents is carried out in the decree of the competent authority (cf. Can. $145 \S 2$ ), nor can this assignment be lost even "by privation" (cf. Can. $184 \S 1$ ). This is one of the decisive aspects that does not allow the baptismal assignment to be considered an ecclesiastical office ${ }^{6}$. The second one is that the office is established in the whole system of organized ecclesiastical action, and its characteristic of "constancy" does not

5 See T. Rincón-Pérez, La liturgia e i sacramenti nel diritto della chiesa, Rome 2014, 176-177.

6 See J.I. Arrieta, „can. 145”, in Exegetical commentary on the Code of canon law, vol. I, Chicago 2004, 700. 
traktować zadania chrzestnego jako urzędu kościelnego ${ }^{6}$. Drugim jest kwestia, że ustanawia się urząd w całym systemie zorganizowanego działania kościelnego, a jego cecha jaką jest „stałość” nie jest związana z jakąś osobą, lecz wynika z potrzeby realizacji celów specjalnie określonych i potrzebnych Kościołowi. Wszystkie elementy urzędu kościelnego powinny być współobecne, dlatego w przypadku chrzestnych mówi się nie o urzędzie, lecz zadaniu, które nie jest ustanawiane ${ }^{7}$. Jeśli zatem nie bezpośrednio, to przynajmniej przez analogię, można uznać zadanie chrzestnego jako „urząd kościelny”, a przez to $\mathrm{w}$ niektórych sytuacjach postępować zgodnie $\mathrm{z}$ normami związanymi z urzędem kościelnym. Dotyczyć to powinno szczególnie przypadków, w których należałoby uznać, że nastąpił „wakat” w pełnieniu zadania chrzestnego.

\section{MOŻLIWOŚĆ USTANOWIENIA ZASTĘPCZEGO RODZICA CHRZESTNEGO W PRZYPADKU PRZYSPOSOBIENIA}

W tej właśnie kwestii pewnego rodzaju novum w prawie kanonicznym wprowadził wspomniany we wstępie Dekret ogólny Konferencji Episkopatu Polski dotyczacy sporzadzenia i modyfikacji aktu chrztu w związu z przysposobieniem z 14 marca 2017 r. ${ }^{8}$, wprowadzając możliwość ustanowienia zastępczych (substytutów) rodziców chrzestnych: „W każdym przypadku przysposabiający mogą zwrócić się do biskupa diecezjalnego o ustanowienie zastępczych (substytutów) rodziców chrzestnych dla przysposobionego dziecka. Ich imiona i nazwiska wpisuje się do aktu chrztu. Wybór nowych chrzestnych

6 Por. J.I. Arrieta, „can. 145”, w: Exegetical commentary on the Code of canon law, vol. I, Chicago 2004, 700.

7 Por. A. Perlasca, „La figura e il ruolo dei padrini nei sacramenti dell'iniziazione cristiana", w: Quando si diventa cristiani. I sacramenti dell'iniziazione: indicazioni canoniche e pastorali, G. Trevisan (ed.), Milano 2003, 325.

8 Por. Dekret ogólny Konferencji Episkopatu Polski dotyczacy sporzadzenia $i$ modyfikacji aktu chrztu w związku z przysposobieniem, w: Akta Konferencji Episkopatu Polski 30(2018) 46-47. [Dalej: Dekret o przysposobieniu]. 
relate to any person, but results from the need to fulfil purposes specifically defined and needed by the Church. All the elements of the ecclesiastical office should be co-present, which is why in the case of godparents one speaks not of an office but of an assignment which is not instituted ${ }^{7}$. Therefore, if not directly, then at least by analogy, it may be possible to consider the baptismal assignment as an "ecclesiastical office" and thus, in certain situations, to act in accordance with the norms of an ecclesiastical office. This applies in particular to cases in which it should be considered that there is a "vacancy" in the functions of a sponsor.

\section{POSSIBILITY OF APPOINTING A FOSTER GODPARENT IN THE EVENT OF ADOPTION}

With respect to this very issue, the new canon law was introduced by the General Decree of the Polish Bishops' Conference on the Preparation and Modification of the Baptismal Act in relation to Adoption of 14 March $2017^{8}$, mentioned in the introduction, which introduces the possibility of appointing foster (substitute) godparents: "In any case, the adopters may request the diocesan bishop to appoint foster (substitute) godparents for the adopted child. Their names shall be entered in the baptismal record. The selection of new sponsors can be combined with an adapted liturgical rite of the renewal of baptismal promises and the blessing of the young child provided for in the liturgical book Rites of Blessing". The Decree on Adoption therefore states that the appointment of substitute godparents can take place ,in any case” of adoption of a child - this stems from the text and

7 Cf. A. Perlasca, „La figura e il ruolo dei padrini nei sacramenti dell'iniziazione cristiana", in: Quando si diventa cristiani. I sacramenti dell'iniziazione: indicazioni canoniche e pastorali, G. Trevisan (ed.), Milano 2003, 325.

${ }^{8} \mathrm{Cf}$. General Decree of the Polish Bishops' Conference on the Preparation and Modification of the Baptismal Act in relation to Adoption, in Acts of the Polish Bishops' Conference 30(2018) 46-47 [hereinafter: Decree on Adoption].

9 Decree on Adoption no. 8. 
można połączyć z odpowiednio dostosowanym obrzędem liturgicznym odnowienie przyrzeczeń chrzcielnych i błogosławieństwem małego dziecka przewidzianym w księdze liturgicznej Obrzędy błogosławieństw"9. Dekret o przysposobieniu określa zatem, że ustanowienie zastępczych rodziców chrzestnych (substytutów) może dokonać się ,w każdym przypadku” dotyczącym przysposobienia dziecka - wynika to z tekstu i kontekstu - a zatem nie tylko w przypadku kiedy tworzy się nowy akt chrztu ${ }^{10}$. Ustanowienie zastępczych rodziców chrzestnych jest możliwe również w przypadkach kiedy przysposobienie nastąpiło po chrzcie dziecka, jednak nie zadecydowano o sporządzeniu nowego aktu urodzenia oraz nowego aktu chrztu. Nowe dane osobowe zostają dopisane do istniejącego już aktu, podobnie dane ustanowionych zastępczych rodziców chrzestnych ${ }^{11}$.

Intencja Prawodawcy partykularnego w tym przypadku jest bardzo wyraźna. Skoro dziecko, które zostało przysposobione wymaga opieki rodzicielskiej i dlatego zostało dane pod opiekę przysposabiających rodziców, to również w sferze duchowej ta pomoc rodziców chrzestnych jest bardzo potrzebna. Dlatego „w każdym przypadku” przysposobienia istnieje możliwość ustanowienia zastępczych (substytutów) rodziców chrzestnych. Biorąc pod uwagę fakt, że w większości przypadków kontakt przysposobionego dziecka z rodzicami chrzestnymi, których otrzymał na chrzcie, będzie utrudniony, a wręcz niemożliwy, a nawet gdyby tak nie było, to jednak rodzice chrzestni mają ,w razie potrzeby (...) wspierać rodziców w staraniu o to, by dziecko doszło do wyznawania wiary i wyrażało ją życiem""12, w tym przypadku mieliby pomagać rodzicom przysposabiającym. W tym kontekście należy zauważyć, że nie byłoby to ani komfortowe ani łatwe, ponieważ ustanowieni na chrzcie rodzice chrzestni i rodzice przysposabiający nie znają się, a w związku z tym zadanie chrzest-

9 Dekret o przysposobieniu nr 8.

10 Por. Dekret o przysposobieniu nr 6.

11 Por. Dekret o przysposobieniu nr 5.

12 „Wprowadzenie ogólne” nr 8, w: Obrzędy chrztu dzieci dostosowane do zwyczajów diecezji polskich, wyd. 3, Katowice 2007, 12. 
the context - and hence not only in the case of a new act of baptism ${ }^{10}$. The appointment of substitute godparents is also possible in cases where the adoption takes place after the child's baptism, but where it has not been decided to draw up a new birth certificate and a new baptismal certificate. The new personal data will be added to the birth certificate, as will the data of the sponsors who have been appointed. ${ }^{11}$

In this instance the intention of the particular Legislator is very clear. Since the child who has been adopted requires parental care and has therefore been given to the care of the adopting parents, this help of the sponsors is also very necessary in the spiritual sphere. Therefore, "in each and every case" of adoption it is possible to appoint substitute (replacement) godparents. Taking into account that in most cases the adopted child's contact with the godparents he or she received at baptism will be difficult, if not impossible, and even if this were not the case, the godparents are nevertheless to "if necessary ... support the parents in their efforts to ensure that the child comes to faith and expresses it with his or her life"12, in this case they would be expected to assist the adoptive parents. In this context, it should be noted that this would be neither comfortable nor easy, since the sponsors and the adoptive parents appointed at the baptism do not know each other, and therefore the baptismal assignment of the sponsors is virtually impossible. It is therefore entirely justified to introduce substitute godparents who can reliably fulfil the assignments entrusted to them by the Church. Their responsibility is explicitly mentioned by the Common Legislator in the Code: "Parents above others are obliged to form their children by word and example in faith and in the practice of Christian life; sponsors and those who take the place of parents are bound by an equal obligation." (Can. $774 \S 2$ ). It is therefore a fundamental assignment ${ }^{13}$. However, it can be argued

${ }^{10} \mathrm{Cf}$. Decree on Adoption no. 6.

$11 \mathrm{Cf}$. Decree on Adoption no. 5.

12 „General Introduction” no. 8, in: Rites of Baptism of Children adapted to the customs of Polish dioceses, 3rd edition, Katowice 2007, 12.

13 Cf. L. Chiappetta, Il Codice di diritto canonico, vol. II, Bologna 2011, 115. 
nych jest właściwie niemożliwe do zrealizowania. Z tego względu jest całkowicie uzasadnione wprowadzenie substytutów rodziców chrzestnych, którzy będą mogli rzetelnie wypełniać zadania powierzone im przez Kościół. Ich odpowiedzialność wyraźnie wspomniana Prawodawca powszechny w Kodeksie: ,rodzice przed innymi mają obowiązek słowem i przykładem formować dzieci w wiwerze i praktyce życia chrześcijańskiego. Podobny obowiązek spoczywa na tych, którzy zastępują rodziców oraz na chrzestnych" (kan. 774 § 2 KPK). Jest to zatem zadanie podstawowe ${ }^{13}$. Można jednak stwierdzić, że wprowadzenie figury zastępczych (substytutów) rodziców chrzestnych, jest nie tylko stworzeniem okazji do realnej pomocy dla rodziców przysposabiających, lecz także zwolnieniem rodziców chrzestnych z moralnego obowiązku przyjętego na chrzcie ich chrześniaka. Zadania, którego albo nie chcą, albo nie mają okazji wypełniać lub nawet nie są w stanie. Na takie zwolnienie wskazywać może użyte określenie „substytut”, pochodzące od łacińskiego czasownika substituo, -ere, co oznacza ,postawić na czyimś miejscu”"14.

\section{SYTUACJE ANALOGICZNE POZA PRZYPADKIEM PRZYSPOSOBIENIA}

W normach generalnych Kodeksu Prawa Kanonicznego Prawodawca zawarł zasadę, że: „urząd kościelny traci się po upływie wyznaczonego czasu, po osiągnięciu określonego prawem wieku, na skutek rezygnacji, przeniesienia, usunięcia a także pozbawienia" (kan. $184 \S 1 \mathrm{KPK}$ ). I chociaż wspomniano już, że tylko per analogiam zadanie chrzestnego można przyrównywać do urzędu kościelnego, to właśnie te sytuacje analogiczne, w których można byłoby dopatrywać się uzasadnienia dla wyznaczenia substytutu rodzica chrzestnego poza przy padkiem przysposobienia, są przyczyną tejże analizy w oparciu o ową analogię.

\footnotetext{
13 Por. L. Chiappetta, Il Codice di diritto canonico, vol. II, Bologna 2011, 115.

14 Por. M. Plezia, Słownik łacińsko-polski, t. V, Warszawa 1999, 263-264.
} 
that the introduction of the foster (substitute) godparents, not only creates an opportunity for real help for the adoptive parents, but also relieves the godparents of a moral obligation accepted at the baptism of their godchild. An assignment which they either do not want to fulfil, do not have the opportunity to fulfil or are not even able to fulfil. Such an exemption may be indicated by the use of the term "substitute", derived from the Latin verb substituo, -ere, which means "to substitute / to put instead."14

\section{ANALOGOUS SITUATIONS EXCEPT IN THE CASE OF ADOPTION}

In the general norms of the Code of Canon Law the legislator has included the principle stating that "an ecclesiastical office is lost by the lapse of a predetermined time, by reaching the age determined by law, by resignation, by transfer, by removal, and by privation." (Can. 184 § 1). And although it has already been mentioned that only per analogiam the baptismal assignment can be compared to the ecclesiastical office, it is precisely these analogous situations, in which one could find justification for appointing a substitute godparent outside the case of adoption, that give rise to the analysis herein on the basis of this analogy.

Therefore, we should first consider cases in which sponsors were appointed at the time of baptism in accordance with the provisions of canon law (cf. Cann. 872-874), but as time has passed it has turned out that one of the prerequisites causing the loss of the ecclesiastical office has occurred, which should be implemented analogously to the baptismal assignment.

As a consequence of the aforementioned premises, it should be stated that the function of the godfather cannot be lost due to the lapse of the time. This is because both children and adult catechumens should be accompanied by at least one sponsor during

14 Cf. M. Plezia, Słownik łacińsko-polski [Latin-Polish Dictionary], vol . V, Warsaw 1999, 263-264. 
Zatem należy w pierwszej kolejności wziąć pod uwagę przypadki, w których podczas chrztu zostali wyznaczeni rodzice chrzestni zgodnie z przepisami prawa kanonicznego (por. kan. 872-874 KPK), jednak w wyniku upływającego czasu okazało się, że zachodzi jedna z przesłanek powodujących utratę urzędu kościelnego, które analogicznie należałoby implementować do zadania chrzestnego.

W konsekwencji wspomnianych przesłanek należy stwierdzić, że funkcji chrzestnego nie można utracić ze względu na upływ wyznaczonego czasu. Wynika to $\mathrm{z}$ tej racji, iż zarówno dzieciom jak i katechumenom dorosłym podczas chrztu powinien towarzyszyć przynajmniej jeden chrzestny ${ }^{15}$. Oznacza to, że zadania chrzestnego nie kończą się w momencie osiągnięcia przez chrześniaka ani pełnoletności, ani tym bardziej dopełnienia całej drogi wtajemniczenia chrześcijańskiego, czyli w momencie przyjęcia sakramentu bierzmowania. Może o tym świadczyć fakt, że Kościół katolicki uznaje istnienie ,pokrewieństwa duchowego”, które istnieje pomiędzy chrzestnym a chrześniakiem, co w Kościele łacińskim do 1983 r. stanowiło przeszkodę do zawarcia małżeństwa (por. can. $1042 \S 1$, $4^{\circ}$ CIC 1917), a w Kościołach katolickich obrządków wschodnich jest przeszkodą do dnia dzisiejszego (por. kan. 811 CCEO). „Pokrewieństwo duchowe" to więź o naturze duchowej, posiadająca swoje uzasadnienie teologiczno-sakramentalne ${ }^{16}$. Oznacza to, że istnienie tej więzi nie jest ograniczone czasem, a zatem również zadania wynikające $\mathrm{z}$ bycia ojcem lub matką chrzestną nie są w żaden sposób ograniczone czasem. Owszem, można uznać, że tak jak w przypadku naturalnych obowiązków rodziców względem dzieci zmieniają się one względem nich w zależności od wieku oraz samodzielności, a w przypadku całkowitego usamodzielnienia się dzieci nabierają

15 „Wprowadzenie ogólne”, nr 8, oraz „Wprowadzenie teologiczne i pastoralne”, nr 43, w: Obrzędy chrześcijańskiego wtajemniczenia dorostych dostosowane do zwyczajów diecezji polskich, Katowice 1998, 12 oraz 33.

16 Por. P. Pinto, Commento al Codice dei Canoni delle Chiese Orientali, Città del Vaticano 2001, 682. 
their baptism ${ }^{15}$. This means that the baptismal assignments do not cease when the godchild reaches the age of majority, let alone when the whole journey of Christian initiation is completed, i.e. when the sacrament of Confirmation is received. This is evidenced by the fact that the Catholic Church recognises the existence of a „spiritual relationship" between a sponsor and the baptized person, which in the Latin Church invalidated marriage until 1983 (cf. Can. $1042 \S 1,4^{\circ}$ CIC 1917) and in the Eastern Rite Catholic Churches is still an obstacle today (cf. Can. 811 CCEO). "Spiritual relationship" is a bond of a spiritual nature, which has its theological and sacramental justification. ${ }^{16}$ It means that this bond is not limited by time and, therefore, neither are the responsibilities of being a sponsor in any way limited by time. It is true that, just as the natural duties of parents towards their children change according to their age and independence, and take on a new character when the children become completely independent, and the same applies to the spiritual duties arising from being a sponsor.

Similarly, it must be stated that the baptismal assignment cannot be invalidated due to some "attained age". This is so for two reasons. First, the ordinary legislature does not legally specify such an age at which the baptismal assignment can cease to exist, which means that it is not possible to set an upper age limit for a sponsor either; second, in view of the fact that the baptismal assignment is unlimited in time, it is not appropriate to limit the sponsor's own age limit for performing the responsibilities assigned to her or him.

However, it seems necessary to present some arguments in favour of the fact that the sponsor in fact ceases to fulfil his/her assignment as a result of certain legal acts (Latin: actus iuridicus), i.e. by resignation,

15 "General Introduction", no. 8, and "Theological and Pastoral Introduction", no. 43, in: : Obrzędy chrześcijańskiego wtajemniczenia dorostych dostosowane do zwyczajów diecezji polskich [Rites of Christian Initiation of Adults Adapted to the Customs of the Polish Dioceses], Katowice 1998, 12 and 33.

${ }^{16}$ Cf. P. Pinto, Commento al Codice dei Canoni delle Chiese Orientali, Città del Vaticano 2001, 682. 
nowego charakteru, tak też jest i z obowiązkami duchowymi wynikającymi z bycia rodzicem chrzestnym.

Podobnie należy stwierdzić, że zadania chrzestnego nie można utracić ze względu na „osiągnięty wiek”. Wynika to z dwóch powodów: po pierwsze, Prawodawca powszechny nie określił prawem takiego wieku utraty zadania, a to oznacza, że nie istnieje też możliwość określenia górnej granicy wieku rodziców chrzestnych; po drugie, ze względu na nieograniczone czasem wypełnianie zadań chrzestnego nie należy także ograniczać wiekiem samego chrzestnego pełnienia przez niego przynależnych mu zadań.

Trzeba przedstawić jednak pewne argumenty, które przemawiają za faktem, iż w wyniku niektórych czynności prawnych (łac. actus iuridicus) chrzestny w istocie przestaje pełnić swoje zadania. Chodzi o czynności prawne takie jak: rezygnacja, przeniesienie, usunięcie i pozbawienie (por. kan. $184 \S 1 \mathrm{KPK}$ ). Oczywiście należy pamiętać tylko o pewnego rodzaju analogii zadania chrzestnego do urzędu kościelnego oraz dostosowaniu tych czynności i okoliczności odpowiednio do zadania chrzestnego.

Pierwszą czynnością prawną mogłaby być rezygnacja, którą należałoby określić jako dobrowolną prośbę zakończenia lub zwolnienia $\mathrm{z}$ urzędu kościelnego, który się wypełnia, dokonaną wobec kompetentnej władzy i przez nią zaakceptowaną ${ }^{17}$. Chociaż łatwo sobie wyobrazić możliwość rezygnacji z zadania chrzestnego, to jednak w praktyce nie stosuje się tego rodzaju czynności prawnej w przypadku zadania chrzestnego. Jest to związane przede wszystkim z faktem, że podczas liturgii chrztu rodzice i rodzice chrzestni wyznają swoją wiarę oraz a sami rodzice chrzestni składają deklarację, iż są gotowi pomagać rodzicom dziecka w wychowaniu go w wierze oraz w życiu zgodnie z Bożymi przykazaniami i w miłości do Boga i bliźniego zgodnie z nauczaniem Jezusa Chrystusa ${ }^{18}$. Z tej

17 Por. J.G. Martín, Le norme generali del Codex Iuris Canonici, Venezia 20156, 806.

18 Por. Obrzędy chrztu dzieci dostosowane do zwyczajów diecezji polskich, nr 39-40, wyd. 3, Katowice 2007, 31. 
by transfer, by removal, and by privation (cf. Can. $184 \S 1$ ). Clearly, only a certain analogy between the baptismal assignment of a sponsor and the ecclesiastical office must be borne in mind, and these actions and circumstances must be adapted accordingly to the baptismal assignment.

The first legal act could be resignation, which should be defined as a voluntary request for termination or dismissal from the ecclesiastical office that one holds, made before a competent authority and accepted by $\mathrm{it}^{17}$. Although it is easy to imagine the possibility of renouncing the baptismal assignment, in practice this kind of legal act does not apply to the baptismal assignment. This is primarily due to the fact that during the liturgy of baptism, the parents and godparents profess their faith and the godparents themselves make a declaration that they are willing to assist the parents of the child in raising them in the faith and in living in accordance with God's commandments and in love for God and neighbour according to the teaching of Jesus Christ ${ }^{18}$. This declaration towards the Church gives rise to the duties of godparents. It is therefore difficult to imagine a situation in which the godparent renounces the accepted assignment and is relieved of the obligations resulting from its acceptance and of moral and legal responsibility for their improper fulfilment (cf. Can. $774 \S 2$ ).

In the case of an ecclesiastical office, it is possible to speak of a transfer when a person is transferred from one ecclesiastical office to another ecclesiastical office and both the former and the latter are subject to the competent ecclesiastical authority which carries out the transfer (cf. Can. $190 \S 1$ ). In such a case, the office from which the transfer is made is lost ${ }^{19}$. It is therefore difficult to imagine an analogous situation for the baptismal assignment. Firstly, it would

17 Cf. J.G. Martín, Le norme generali del Codex Iuris Canonici, Venezia 20156, 806.

$18 \mathrm{Cf}$. Obrzędy chrztu dzieci dostosowane do zwyczajów diecezji polskich [Rites of Baptism of Children Adapted to the Customs of the Dioceses of Poland], no. 39-40, 3rd ed, Katowice 2007, 31.

19 Cf. V. De Paolis, A. D’Auria, Le Norme Generali, Roma 2014, 518. 
deklaracji wobec Kościoła rodzą się obowiązki rodziców chrzestnych. Trudno zatem wyobrazić sobie sytuację, w której chrzestny rezygnuje z przyjętego zadania i zostaje zwolniony z obowiązków wynikających z jego przyjęcia oraz odpowiedzialności moralnej i prawnej za ich nienależyte wypełnianie (por. kan. 774 § 2 KPK).

W przypadku urzędu kościelnego o przeniesieniu można mówić wtedy, kiedy to dana osoba zostaje przeniesiona z jednego urzędu na drugi urząd kościelny i zarówno jeden jak i drugi podlega kompetentnej władzy kościelnej, która dokonuje przeniesienia (por. kan. 190 $\S 1 \mathrm{KPK}$ ). W takim przypadku traci się urząd, z którego następuje przeniesienie $^{19}$. Trudno jest zatem wyobrazić sobie analogiczną sytuację w przypadku zadania chrzestnego. W pierwszej kolejności należałoby ustalić, kto powierza zadanie chrzestnego: rodzice czy szafarz chrztu. Z tego wynikałoby, kto jest kompetentny do tego, aby dokonać takie przeniesienia. Jednakże trudno jest sobie wyobrazić, na jakie inne zadanie lub urząd takie przeniesienie mogłoby nastąpić. A zatem również ta możliwość nie jest właściwa dla utraty zadania rodzica chrzestnego.

Inną czynnością prawną, którą należy wziąć pod uwagę, jest usunięcie $z$ urzędu, które jest formą oddalenia lub zwolnienia osoby $\mathrm{z}$ pełnionego urzędu, dokonane $\mathrm{z}$ mocy samego prawa lub przez kompetentną władzę ${ }^{20}$. Przypadek usunięcia właściwie realizuje się w sytuacji przysposobienia. To rodzice chrzestni, którzy zostali wybrani przez rodziców biologicznych, po przysposobieniu traca to zadanie, a na ich miejsce zostają wybrani przez rodziców przysposabiających zastępczy rodzice chrzestni. Jednak w przypadkach innych niż przysposobienie, nie można się zgodzić na możliwość usunięcia z zadania chrzestnego. Skoro jest to zadanie, które wynika z pełnionej funkcji podczas liturgii sakramentu chrztu, to realizacja tych obowiązków powinna wynikać przede wszystkim z tego wydarzenia. Nie można akceptować zmienności woli rodziców czy

19 Por. V. De Paolis, A. D’Auria, Le Norme Generali, Roma 2014, 518.

20 Por. J.G. Martín, Le norme generali del Codex Iuris Canonici, Venezia $2015^{6}$, 819. 
have to be established who entrusts the baptismal assignment, i.e. the parents or the baptismal minister. It would then be apparent who is competent to make such a transfer. However, it is difficult to imagine to which other assignment or office such a transfer could take place. Therefore, also this possibility is not appropriate for the loss of the baptismal assignment.

Another legal act to be taken into account is removal from office, which is a form of dismissal or removal of a person from office, carried out by operation of law alone or by a competent authority ${ }^{20}$. The case of removal actually occurs in the situation of adoption. It is the godparents who were chosen by the biological parents who, after the adoption, lose this assignment and are replaced by substitute godparents chosen by the adopting parents. However, in cases other than adoption, the possibility of removal from the baptismal assignment cannot be accepted. Since it is an assignment which derives from the function performed during the liturgy of the sacrament of Baptism, the performance of these duties should derive primarily from that event. It is not acceptable to change the will of the parents or various other circumstances to change the godparents. However, considering the fact that "a person cannot be removed from an office conferred for an indefinite period of time except for grave causes and according to the manner of proceeding defined by law." (Can. $193 \S 1)$. The legislator sets a number of canonical requirements for those who are to be permitted to take on the function of sponsor (cf. Can. $874 \S 1$ ), and given that these conditions may be considered as qualities necessary for the good performance of the baptismal assignment, should someone fail to meet a given criterion after some time - considering this as a ,grave reason" - consideration could be given to the possibility of removing such a sponsor in order to appoint a new, more suitable one. It should be noted that this would primarily concern the requirement of the Legislator that the sponsor "leads a life of faith in keeping with the function to be taken on" (Can.

${ }^{20}$ Cf . J.G. Martín, Le norme generali del Codex Iuris Canonici, Venezia 2015", 819. 
też różnych innych okoliczności do tego, aby zmieniać rodziców chrzestnych. Jednakże zważywszy na fakt, że: ,z urzędu nadanego komuś na czas nieokreślony nie można go usunąć, chyba że na skutek poważnych przyczyn" (kan. $193 \S 1$ KPK). Prawodawca stawia szereg wymagań kanonicznych w stosunku do tych, którzy mają być chrzestnymi (por. kan. $874 \S 1 \mathrm{KPK}$ ), a biorąc pod uwagę fakt, że warunki te mogą być uznane za przymioty konieczne do dobrego sprawowania zadania chrzestnego, w przypadku gdy po jakimś czasie ktoś nie spełnia danego kryterium - uznając to jako „poważną przyczynę" - można byłoby rozważyć możliwość usunięcia takiego chrzestnego w celu wyznaczenia nowego, bardziej odpowiedniego. Należy stwierdzić, że chodziłoby przede wszystkim o wymaganie Prawodawcy, iż chrzestny ,prowadzi życie zgodne z wiarą i odpowiadające funkcji, jaką ma pełnić” (kan. 874 § 1, 3 KPK). Ponadto analogicznie do urzędu kościelnego można stwierdzić, że z mocy samego prawa takie zadanie powinien utracić ten „kto publicznie odstąpił od wiary katolickiej lub wspólnoty z Kościołem” (kan. 194 $\S 1,2$ KPK). Ten zapis nie dotyczy jednak chrzestnego prawosławnego, który od początku nie spełniał kryterium bycia katolikiem, jednak na podstawie wyjątkowej bliskości doktryny obu Kościołów mógł zostać chrzestnym wraz z katolikiem ${ }^{21}$.

Zdecydowanie podobne stanowisko można obrać w przypadku pozbawienia zadania chrzestnego, porównując $\mathrm{z}$ analogicznym pozbawieniem urzędu kościelnego kogoś, wobec kogo można dokonać tego jako karę za przestępstwo, dokonane zgodnie z przepisami prawa (por. kan. 196 KPK). Pozbawienie może mieć tylko charakter penalny $^{22}$. Chociaż ciężko jest wyobrazić sobie karę za jakieś konkretne przestępstwo wymierzoną w celu pozbawienia zadania chrzestnego, to jednak warto zastanowić się, czy w przypadku kar zaciągnię-

21 Papieska Rada do Spraw Jedności Chrześcijan, Dyrektorium ekumeniczne, 25 marca 1993 r., nr 98; w: AAS 85 (1993) 1039-1119. Polski przekład: Ut unum. Dokumenty Kościoła katolickiego na temat ekumenizmu 1982-1998, S.C. Napiórkowski (red.), Lublin: Towarzystwo Naukowe Katolickiego Uniwersytetu Lubelskiego.

22 Por. V. De Paolis, A. D'Auria, Le Norme Generali, Roma 2014, 523. 
$874 \S 1)$. Moreover, by analogy with the ecclesiastical office, it may be stated that by virtue of the very law such an assignment should be lost by "a person who has publicly defected from the Catholic faith or from the communion of the Church" (Can. $194 \S 1,2)$. This provision, however, does not apply to an Orthodox godparent, who from the very beginning did not meet the criterion of being a Catholic, but on the basis of the exceptional closeness of the doctrine of both Churches could become a godparent along with a Catholic ${ }^{21}$.

Considerably similar positions can be taken in the case of privation of the baptismal assignment, comparing it with an analogous privation of the ecclesiastical office of someone against whom this can be done a penalty for a delict, carried out only according to the provisions of the law (cf. can. 196). The privation can only be of a penal nature ${ }^{22}$. Although it is difficult to imagine a penalty for a specific offence imposed with the aim of depriving a sponsor of his or her baptismal assignment, it is worth considering whether, in the case of penalties imposed by law, the possibility of depriving a godparent of his or her baptismal assignment should not also be considered, particularly if the child's parents or the godparent himself or herself so request. These are above all the penalties of excommunication by the law itself for the crimes of heresy, schism or apostasy (cf. Can. 751, 1364) or ab homine (by judicial act of man), i.e. physical coercion against the Roman Bishop (cf. Can. $1370 \S 1$ ), though it must certainly be noted that the latter occurs relatively rarely in relation to the others mentioned. It would not, however, concern other offences punishable by excommunication, the release of which could be effected in the internal forum (cf. Can. 1398).

${ }^{21}$ Pontifical Council for Promoting Christian Unity, Directory for the Application of Principles and Norms on Ecumenism, 25 March1993, 1993, no. 98; in: AAS 85 (1993) 1039-1119; Polish translation: Ut unum. Dokumenty Kościoła katolickiego na temat ekumenizmu 1982-1998, S.C. Napiórkowski (ed.), Lublin: Towarzystwo Naukowe Katolickiego Uniwersytetu Lubelskiego.

${ }^{22}$ Cf. V. De Paolis, A. D'Auria, Le Norme Generali, Roma 2014, 523. 
tych z mocy samego prawa, nie należałoby rozważyć możliwości pozbawienia również zadania chrzestnego, szczególnie jeśliby wnioskowali o to rodzice dziecka lub sam chrześniak. Chodzi tutaj przede wszystkim o karę ekskomuniki z mocy samego prawa zaciągniętą za przestępstwa herezji, schizmy czy apostazji (por. kan. 751, 1364 KPK) lub o przymus fizyczny wobec Biskupa Rzymskiego (por. kan. 1370 § $1 \mathrm{KPK}$ ), choć z pewnością należy stwierdzić, że ostatnie występuje stosunkowo sporadycznie w relacji do pozostałych wymienionych. Nie chodziłoby jednak o inne przestępstwa zagrożone karą ekskomuniki, a których zwolnienie mogłoby dokonać się na forum wewnętrznym (por. kan. 1398 KPK).

Nie należy zapominać, że w przypadku urzędu kościelnego może on zawakować również w przypadku śmierci tego, komu został ten urząd powierzony. Przez analogię można stwierdzić, że również zadanie rodzica chrzestnego zostałoby uznane za wakujące w przypadku śmierci wszystkich rodziców chrzestnych. Można byłoby wysunąć takie wnioski na podstawie przepisów prawnych, które znajdują się zarówno w Kodeksie, jak i w rubrykach liturgicznych ${ }^{23}$, a dotyczących konieczności wyznaczenia tylko jednego chrzestnego lub jednej chrzestnej, albo obojga chrzestnych (por. kan. 873 KPK). W konsekwencji w przypadku śmierci jednego tylko rodzica nie należy twierdzić, że zadanie chrzestnego nie jest wypełniane, ponieważ jest jeszcze drugi rodzic chrzestny. O wakacie na tej funkcji, czy inaczej zadaniu, można byłoby mówić, gdyby nie było osoby wyznaczonej do jego wykonywania, ze względu na jej śmierć.

Ponadto należy uznać, że również przez analogię do urzędu kościelnego, zadanie chrzestnego jest wakujące, jeżeli w momencie udzielania sakramentu chrztu nie było wyznaczonego żadnego chrzestnego. Nie chodzi tutaj o przypadek niebezpieczeństwa śmierci, z którego nowo ochrzczony wyszedł po przyjęciu chrzty. W takiej sytuacji należałoby dokonać „uzupełnienia sakramentu chrztu” w kościele $\mathrm{i}$ w nim jest przewidziane ustanowienie chrzestnych, mimo iż

23 Por. „Wprowadzenie ogólne” nr 9, pkt 5, w: Obrzędy chrztu dzieci dostosowane do zwyczajów diecezji polskich, wyd. 3, Katowice 2007, s. 13. 
One should not forget that in the case of an ecclesiastical office, it can also become vacant upon the death of the person to whom the office is entrusted. By analogy, it can be concluded that also the baptismal assignment would be considered to be vacant upon the death of both godparents. This conclusion could be drawn on the basis of the legal provisions found both in the Code and in the liturgical rubrics ${ }^{23}$, concerning the necessity of appointing only one godfather or one godmother or both godparents (cf. Can. 873). Consequently, in the event of the death of only one parent, it should not be claimed that the baptismal assignment is not fulfilled, since there is still the other godparent. It would be possible to speak of a vacancy in this function or, in other words, assignment, if there is no person appointed to perform it, due to his or her death.

Furthermore, it must be recognized that also by analogy with the ecclesiastical office, the baptismal assignment is vacant if no godparent was appointed at the time of the receiving the sacrament of baptism. This is not a case of danger of death from which the newly baptised person has emerged after receiving baptism. In such a situation, the ,completion of the sacrament of baptism” would have to be done in the church, and therein the appointment of godparents is provided for, even though they were not present at the time of baptism, as is evident from the context ${ }^{24}$. It concerns more the situations that may arise when the minister appoints a witness to baptism (cf. Can. 875). Such a procedure could take place when the parents are unable to appoint any sponsor who meets the legal requirements. Since the absence of a sponsor cannot be a reason for denying the right to administer the sacrament of baptism, a baptismal witness would

${ }^{23}$ Cf. „General Introduction” no. 9, point 5, in: Rites of Baptism of Children Adapted to the Customs of the Dioceses of Poland, 3rd edition, Katowice 2007, p. 13. .

${ }^{24}$ Cf. „Przyniesienie do Kościoła dziecka już ochrzczonego. Obrzęd przyjęcia” [Bringing an already baptised child into the Church. Rite of Reception], no. 190, in: Obrzędy chrztu dzieci dostosowane do zwyczajów diecezji polskich [Rites of Baptism of Children Adapted to the Customs of the Dioceses of Poland], 3rd edition, Katowice 2007, 112. 
nie byli obecni w momencie chrztu św., co wynika z kontekstu ${ }^{24}$. Dotyczy to bardziej sytuacji, które mogą pojawić się w przypadku wyznaczenia przez szafarza świadka chrztu (por. kan. $875 \mathrm{KPK}$ ). Takie postępowanie mogłoby mieć miejsce, w przypadku kiedy rodzice nie mogą wyznaczyć żadnego chrzestnego spełniającego wymagania prawa. Ponieważ brak rodzica chrzestnego nie może stanowić powód odmowy prawa do udzielenia sakramentu chrztu, należałoby wtedy wyznaczyć świadka chrztu. Praktyka duszpasterska w wielu krajach pokazuje, że sytuacje takie mogą mieć coraz częściej miejsce, ponieważ wiele osób nie może sprostać wymaganiom stawianym rodzicom chrzestnym ${ }^{25}$. W ten sposób zadanie chrzestnego pozostawałoby nieobsadzone.

W takich sytuacjach, można stwierdzić, że funkcja rodzica chrzestnego rzeczywiście mogłaby zostać uznana jako wakująca. Jednakże przepisy prawa kanonicznego zawarte w Kodeksie Prawa Kanonicznego - przynajmniej bezpośrednio - nie przewidują takiej sytuacji. Należy zatem zastosować odpowiednie przepisy interpretacyjne w celu próby rozwiązania tej kwestii.

\section{ZASADY INTERPRETACYJNE}

W pierwszej kolejność należy stwierdzić, że Kodeks Prawa Kanonicznego nie wspomina, jak należy postąpić w przypadku braku rodziców chrzestnych choć jest to zadanie ważne dla rozwoju wiary dzieci, które przyjęły chrzest, ponieważ wspiera rodziców w ich obowiązku wychowania w wierze katolickiej potomstwa; a nawet w przypadku dorosłego chrzestny pomaga mu we właściwym życiu zgodnym z wiarą i przyjętymi zasadami chrześcijańskimi wynikającymi z Ewangelii. Można zatem stwierdzić, że w Kodeksie Prawa Kanonicznego w tym aspekcie znajduje się luka prawna.

24 Por. „Przyniesienie do Kościoła dziecka już ochrzczonego. Obrzęd przyjęcia”, nr 190, w: Obrzędy chrztu dzieci dostosowane do zwyczajów diecezji polskich, wyd. 3, Katowice 2007, 112.

25 Por. B. Pighin, Diritto sacramentale canonico, Venezia 2016, 117-118. 
then have to be appointed. Pastoral practice in many countries shows that such situations can occur more and more frequently because many people cannot meet the requirements imposed on godparents ${ }^{25}$. This would leave the baptismal assignment vacant.

In such situations, it could be argued that the function of sponsor could indeed be considered as vacant. However, the provisions of canon law contained in the Code of Canon Law do not provide for such a situation, at least not directly. It is therefore necessary to apply relevant rules of interpretation in order to resolve this issue.

\section{RULES OF INTERPRETATION}

First of all, it should be stated that the Code of Canon Law does not mention how to act if there is no sponsor, although it is so important for the development of faith of children who have received baptism, since it supports parents in their duty to bring up their offspring in the Catholic faith; and even in the case of an adult, a sponsor helps him/her to live a proper life which is in harmony with the faith and the accepted Christian principles resulting from the Gospel. It can therefore be concluded that there is lacuna in the Code of Canon Law in this aspect.

Such a statement is especially justified if we take into consideration Can. $893 \S 2$, in which the legislator strongly encourages that a witness of Confirmation should be one of the godparents of a candidate for this sacrament. However, it does not provide any solution if this is not possible. It should only be noted that the Legislator indirectly offers the possibility of remedying the absence of the godparent, since if $\mathrm{s} /$ he is unable to fulfil his or her assignment during Confirmation, the witness may be anyone who fulfils the conditions contained in Can. $893 \S 1$, which is a reference to the conditions for candidates for sponsors. However, this is not a direct solution to the problem and, moreover, it is a solution concerning only the moment of reception of the sacrament of Confirmation and the time after it. This, in turn,

25 Cf. B. Pighin, Diritto sacramentale canonico, Venezia 2016, 117-118. 
Szczególnie takie stwierdzenie jest uzasadnione, jeśli weźmie się pod uwagę kan. 893 § 2 KPK, w którym Prawodawca usilnie zachęca, aby świadkiem bierzmowania był ktoś z chrzestnych kandydata do tego sakramentu. Nie podaje jednak rozwiązania w przypadku niemożliwości. Należy jedynie zauważyć, że Prawodawca pośrednio daje możliwość zaradzenia nieobecności rodzica chrzestnego, ponieważ jeśli ten nie może wypełnić swojego zadania w trakcie bierzmowania, świadkiem może być każdy kto spełnia warunki zawarte w kan. 893 $\S 1 \mathrm{KPK}$, które jest odesłaniem do warunków stawianych kandydatom na rodziców chrzestnych. Jednakże nie jest to bezpośrednie rozwiązanie kwestii, a ponadto jest to rozwiązanie dotyczące momentu przyjęcie sakramentu bierzmowanie i czasu po nim. To zaś nie rozwiązuje wszystkich kwestii dotyczących wakatu w pełnieniu zadania rodzica chrzestnego.

Dlatego warto przeanalizować postępowanie, które nakazuje Prawodawca w celu właściwego zinterpretowania istniejących przepisów, które mogą nas doprowadzić do ciekawych wniosków.

W przypadku braku prawnego rozwiązania w jakiejś kwestii za pomocą wyraźnej ustawy, powszechnej lub partykularnej, albo prawa zwyczajowego: ,sprawa-z wyjątkiem karnej - winna być rozstrzygnięta $\mathrm{z}$ uwzględnieniem ustaw wydanych w podobnych sprawach, ogólnych zasad prawnych z zachowaniem słuszności kanonicznej, jurysprudencji, praktyki Kurii Rzymskiej oraz powszechnej i stałej opinii uczonych" (kan. 19 KPK). W ten sposób Prawodawca powszechny poleca rozwiązać problem luki prawnej, a zatem należy zastosować ten sposób postępowania w przypadku znalezienia odpowiedzi w kwestii postępowania w przypadku braku rodziców chrzestnych w życiu dziecka ochrzczonego lub dorosłego neofity, który potrzebuje jeszcze przewodnika w wierze.

Stwierdzono już, że w prawie powszechnym Kościoła nie ma wyraźnej ustawy, która dawałaby rozwiązanie dla tej kwestii. W aktach Konferencji Episkopatu Polski można znaleźć pewnego rodzaju rozwiązanie, które zostało opracowane przez Komisję Wychowania Katolickiego, a zawartej we wskazaniach dotyczących przygotowania do przyjęcia sakramentu bierzmowania. W tym dokumencie 
does not resolve all the issues concerning the vacancy in the role of sponsor.

It is therefore worth analysing the procedure laid down by the Legislator in order to correctly interpret existing provisions, which may lead to some interesting conclusions.

If there is no legal solution by means of an express law, universal or particularistic, or by common law, ,a case, unless it is penal, must be resolved in light of laws issued in similar matters, general principles of law applied with canonical equity, the jurisprudence and practice of the Roman Curia, and the common and constant opinion of learned persons" (Can. 19). In this way, the universal Legislator instructs to solve the problem of lacuna in the law, and hence this way of proceeding should be applied when finding an answer to the question of how to deal with the absence of godparents in the life of a baptized child or an adult neophyte who still needs a guide in the faith.

It has already been stated that there is no explicit law in the universal law of the Church which would provide a solution to this issue. In the acts of the Polish Bishops' Conference a certain solution can be found, which was elaborated by the Commission for Catholic Education and is contained in the guidelines for the preparation for the reception of the sacrament of Confirmation. The document reads that ,in order to make explicit the unity of the sacraments of Baptism and Confirmation, the witnesses to Confirmation should be the godparents, provided they continue to be a believer and practicing Catholics (cf. CCC 1309). Where it is not possible, a witness may be a person who has already received all the sacraments of Christian initiation, is over 16 years of age and is a believer and practising Catholic." ${ }^{26}$ It can therefore be concluded that particularistic law provides solutions to certain issues. It concerns the case

${ }^{26}$ Commission for Catholic Education, „Guidelines of the Polish Bishops' Conference on Preparation for the Reception of the Sacrament of Confirmation," (March 14, 2017), no. 17, in Acts of the Polish Bishops' Conference 29 (2017) 65-70 [hereinafter: Guidelines]. 
czytamy, że: „w celu wyraźnego zaznaczenia jedności sakramentów chrztu i bierzmowania świadkami bierzmowania powinni być rodzice chrzestni, o ile w dalszym ciągu są wierzącymi i praktykującymi katolikami (por. KKK 1309). Tam, gdzie nie jest to możliwe, świadkiem może być osoba, która już przyjęła wszystkie sakramenty inicjacji chrześcijańskiej, ukończyła 16. rok życia oraz jest wierzącym i praktykującym katolickiej”"26. Można zatem stwierdzić, że prawo partykularne podaje rozwiązania w pewnych kwestiach. Chodzi o przypadek, w którym rodzice chrzestni nie są już osobami wierzącymi i praktykującymi, co ciekawe nie zostały użyte w dokumencie jako źródło przepisy prawa kanonicznego, a jedynie wyjaśnienie z Katechizmu Kościoła Katolickiego i to, w mojej ocenie, nie do końca właściwie, ponieważ bardziej właściwym byłoby odniesienie do artykułu dotyczącego ,świadka bierzmowania"27.

W każdym razie można jeszcze zauważyć, że wspomniany dokument stwierdza, iż w przypadkach, gdzie nie jest możliwe wyznaczenie na świadka bierzmowania rodzica chrzestnego, powinno się wyznaczyć osobę spełniającą warunki stawiane przy chrzcie kandydatom na rodziców chrzestnych (por. kan. 874, 893 KPK).

Wskazania Konferencji Episkopatu Polski dają rozwiązania, ale nie są ustawą. Można byłoby je podważyć, ponieważ nie są źródłem prawa kanonicznego. Jest to dokument, który nie został określony co do gatunku prawnego. Dokument nie otrzymał nawet rangi instrukcji (por. kan. 34 KPK). Niemniej jednak można stwierdzić, że Wskazania przywołują rozwiązanie, które jest już podane przez Prawodawcę powszechnego w Kodeksie Prawa Kanonicznego. A mianowicie, że w momencie przyjmowania sakramentu bierzmowania świadkiem tego sakramentu swojego chrześniaka, powinien być chrzestny (por. kan. 893 § 2 KPK). Jeżeli nie jest to możliwe, może nim być ktoś, kto spełnia warunki określone dla chrzestnych (por. $893 \S 1,874$

26 Komisja Wychowania Katolickiego, ,Wskazania Konferencji Episkopatu Polski dotyczące przygotowania do przyjęcia sakramentu bierzmowania", (14 marca 2017 r.), nr 17, w: Akta Konferencji Episkopatu Polski 29 (2017) 65-70. [Dalej: Wskazania].

27 Por. KKK 1311. 
in which the godparents are no longer believers and practicing Catholics; interestingly, the canon law is not referred to as a source in the document, but only as an explanation from the Catechism of the Catholic Church, and in the author's opinion this is not quite correct, since it would be more appropriate to refer to the article on the "Confirmation witness"27.

Nevertheless, it may also be noted that the aforementioned document states that whenever it is not possible to appoint a sponsor as a witness to Confirmation, a person who fulfils the requirements for a sponsor at baptism should be appointed (cf. Cann. 874, 893).

The Guidelines of the Polish Bishops' Conference provide solutions but they do not constitute a law. They could be undermined as they are not a source of canon law. It is a document that has not been specified as to its legal genre, and it has not even been given the status of an instruction (cf. Can. 34). Nevertheless, it can be stated that the Guidelines evoke a solution that is already given by the universal Legislator in the Code of Canon Law. Namely, that at the moment of receiving the sacrament of Confirmation, the witness of this sacrament for one's godchild should be the sponsor (cf. Can. $893 \S 2$ ). In cases where this is not possible, it may be someone who meets the conditions laid down for a sponsor (cf. Cann. $893 \S 1,874$ ). It may therefore be presumed that this is an indirect establishment of substitution or assistance for the sponsors, since the assignment of the confirmation witness is to provide "spiritual assistance" 28 . The introduction to the sacrament of Confirmation explains more precisely what it involves: "Each candidate is usually accompanied by a witness who brings him or her to receive the sacrament, presents him or her to the minister of confirmation for the anointing with the crucifix, and will then assist in fulfilling the promises made at baptism faithfully, according to the Holy Spirit received. In view of contemporary pastoral conditions, it is appropriate that the sponsor, if present, also be a witness of Confirmation. In this

\footnotetext{
27 Cf. CCC 1311.

28 CCC 1311.
} 
KPK). Można zatem domniemywać, że jest to pośrednie ustanowienie zastępstwa lub pomocy dla rodziców chrzestnych, ponieważ zadanie świadka bierzmowania jest niesienie „,pomocy duchowej"28. Dokładniej na czym ma ona polegać, wyjaśnia wprowadzenie do sakramentu bierzmowania: „Każdemu kandydatowi zwykle towarzyszy świadek, który przyprowadza go do przyjęcia sakramentu, przedstawia szafarzowi bierzmowania do namaszczenia krzyżmem, a potem będzie pomagał w wiernym wypełnianiu przyrzeczeń złożonych na chrzcie, według otrzymanego Ducha Świętego. Ze względu na współczesne warunki pastoralne wypada, aby chrzestny, jeżeli jest obecny, był także świadkiem bierzmowania. W ten sposób bowiem jaśniej ukazuje się związek między chrztem i bierzmowaniem, a funkcje i obowiązki chrzestnego są skuteczniej wypełniane. Nie wyklucza się jednak możliwości wybrania osobnego świadka bierzmowania. Także rodzice mogą osobiście przedstawiać swoje dzieci do bierzmowania. Ordynariusz miejsca, zważywszy okoliczności czasu i miejsca, ustala, jaki sposób postępowania należy zachować w jego diecezji" ${ }^{29}$. Należy zauważyć, że pojawia się w tym zapisie sprzeczność z Kodeksem z 1983 r., ponieważ prawo kanoniczne zabrania, aby świadkami bierzmowania, podobnie jak chrzestnymi byli rodzice dziecka (por. kan. $893 \S 1,874,5 \mathrm{KPK}$ ). Jest to zgodne z zapisem normy generalnej, która stwierdza, że nie zmienia się prawa liturgicznego, jeśli jest zgodne z obowiązującym prawem kanonicznym, jednakże w przypadku kolizji norm należy zastosować postanowienia kodeksowe (por. kan. 2 KPK). Potwierdza to jednak zastosowane rozwiązanie we Wskazaniach Konferencji Episkopatu Polski $^{30}$. Jest to uzasadnione przede wszystkim ową pomocą duchową, którą ma pełnić świadek bierzmowania, a która ma być dodatkową pomocą dla rodziców naturalnych lub prawnych opiekunów. Chociaż Kodeks Prawa Kanonicznego z 1983 roku nie wspomina

28 KKK 1311.

29 Por. „Wprowadzenie teologiczne i past_oralne”, nr 5, w: Obrzędy bierzmowania dostosowane do zwyczajów diecezji polskich, wyd. 3, Katowice 2019, 16.

30 Por. Wskazania nr 18. 
way the link between Baptism and Confirmation is made clearer and the functions and duties of the sponsor are fulfilled more effectively. However, it is not impossible to choose a separate witness for Confirmation, as well as parents may personally present their children for Confirmation. Taking into account the circumstances of time and place, the Ordinary in charge determines the procedure to be followed in his diocese." 29 It should be noted that there is a contradiction in this provision with the 1983 Code, since canon law forbids that witnesses to Confirmation or sponsors be the child's parents (cf. Cann. $893 \S 1,874,5$ ). This is in line with the provision of the general norm, which states that liturgical law is not to be changed if it is in conformity with current canon law; however, where there is a conflict of norms, the provisions of the Code are to be applied (cf. Can. 2). Nevertheless, this is confirmed by the solution applied in the Guidelines of the Polish Bishops' Conference ${ }^{30}$. This is justified above all by this spiritual assistance which the witness to Confirmation is to provide as an additional help to natural parents or legal guardians. Although the 1983 Code of Canon Law does not mention it, the existence of the duties of the Confirmation witness after the celebration of the sacrament to the one whom he or she accompanied to Confirmation testifies to the existence of a spiritual relationship between them, comparable to that which arises between sponsor and godchild at Baptism. The existence of such a spiritual relationship is attested to by the old Code, which noted the formation of such a spiritual bond at the moment of the sacrament of Confirmation between the Confirmed and his/her witness (cf. Can. 797 CIC 1917). And although it does not currently constitute an obstacle to marriage, it testifies to a kind of possibility of introducing foster (substitute) godparents at the moment of the sacrament of Confirmation. Given that the old Code required that the witness to Confirmation be

${ }^{29}$ Cf. „Wprowadzenie teologiczne i past_oralne" [,Theological and Pastoral Introduction"], no. 5, in: Confirmation Rites Adapted to the Customs of the Dioceses of Poland, 3rd edition, Katowice 2019, 16.

30 Cf. Guidelines no. 18. 
o tym, to jednak istnienie obowiązków świadka bierzmowania po celebracji sakramentu wobec tego, któremu towarzyszył w przyjęciu bierzmowania, świadczy o istnieniu między nimi pokrewieństwa duchowego, porównywalnego do tego, które powstaje w momencie sakramentu chrztu między chrzestnym a chrześniakiem. $O$ istnieniu takiego pokrewieństwa duchownego świadczy stary Kodeks, który zauważał powstanie takiej więzi duchowej w momencie sakramentu bierzmowania pomiędzy bierzmowanym, a jego świadkiem (por. can. 797 CIC 1917). I chociaż obecnie nie stanowi ono przeszkody do zawarcia małżeństwa, to jednak świadczy o swoistego rodzaju możliwości wprowadzenia zastępczych (substytutów) rodziców chrzestnych w momencie sakramentu bierzmowania. Zważywszy na fakt, że stary Kodeks wymagał, żeby świadkiem bierzmowania była tej samej płci co kandydat (por. can. $796 \S 2$ CIC 1917), teza jest bardzo mocno uzasadniona ${ }^{31}$.

Powstaje pytanie, czy istnieją też inne momenty, w których byłoby to możliwe. Ponieważ w innych sytuacjach nie znajdziemy takiego rozwiązania w prawie powszechnym. Należy zauważyć, że w prawie partykularnym do 2017 roku w Polsce też nie istniało paralelne miejsce, na którym można byłoby wyprowadzić jakąś praktykę, która byłaby próbą rozwiązania problemu luki prawnej w tej materii. W momencie wejścia Dekretu o przysposobieniu pojawił się taki dokument w prawie partykularnym w Polsce, który można zastosować jako miejsce paralelne do wszystkich przypadków, które można określić jako lukę prawną w kwestii ,wakującego" zadania rodzica chrzestnego. Należy zatem stwierdzić, że skoro powstał dokument, który traktuje podobną sprawę, a w przypadku Konferencji Episkopatu Polski dekret ogólny o przysposobieniu należy traktować na równi z ustawami (por. kan. 29, 30, 455, 877 § 3 KPK), to w konsekwencji istnieje dokument, który uprawnia do zastosowania go przez analogię do podobnych sytuacji nierozstrzygniętych przez Prawodawcę powszechnego i prawodawcę partykularnego (por. kan. 19 KPK).

31 Por. E. Frank, I sacramenti dell'Iniziazione, della Penitenza e dell'Unzione degli infermi, Roma 2012, 71. 
of the same sex as the candidate (cf. Can. $796 \S 2$ CIC 1917), the thesis is very much justified ${ }^{31}$.

The question arises as to whether there are other times when this would be possible. For in other situations we do not find such a solution in common law. It should be noted that in the particularistic law until 2017 in Poland also there was no parallel point on which it would be possible to derive some practice in an attempt to solve the legal gap in this matter. When Decree on Adoption entered into force, such a document appeared in particularistic law in Poland, which can be used as a parallel site for all cases that can be defined as lacuna in the law on the issue of the ,vacant" baptismal assignment. It must therefore be concluded that since there is a document which treats a similar matter, and in the case of the Polish Bishops' Conference, the general decree on adoption is to be treated on an equal footing with the Acts (cf. Cann. 29, 30, 455, $877 \S 3$ ), there is consequently a document which authorises its application by analogy to similar situations unsettled by the universal Legislator and the particularistic legislator (cf. Can. 19). And yet, it is not necessary to rely on all means of closing lacuna in the law, as one of those listed in the general norms of the Code is sufficient. ${ }^{32}$

\section{POSSIBILITY TO APPOINT SUBSTITUTE GODPARENTS}

Whenever foster (substitute) godparents are appointed for the sake of adoption, the matter must be brought before the diocesan bishop. The wording of Decree on Adoption points out that it is the diocesan bishop who makes the decision in this case ${ }^{33}$.

31 Cf. E. Frank, I sacramenti dell'Iniziazione, della Penitenza e dell'Unzione degli infermi, Roma 2012, 71.

32 Cf. J.G. Martín, Le norme generali del Codex Iuris Canonici, Venezia 2015 155.

33 Cf. Decree on Adoption, no. 8. 
A przecież nie trzeba opierać się na wszystkich środkach uzupełnienia luki prawnej, ponieważ wystarczy jeden z wymienionych w normach generalnych Kodeksu ${ }^{32}$.

\section{MOŻLIWOŚĆ USTANOWIENIA ZASTĘPCZYCH RODZICÓW CHRZESTNYCH}

W każdym przypadku ustanawiania zastępczych (substytutów) rodziców chrzestnych ze względu na przysposobienie należy sprawę przedstawić biskupowi diecezjalnemu. Sformułowanie zawarte w Dekrecie o przysposobieniu sugeruje, że to właśnie biskup diecezjalny podejmuje decyzję $\mathrm{w}$ tej sprawie ${ }^{33}$.

W takim wypadku w każdej sytuacji paralelnej, gdzie zachodzi wakat zadania rodzica chrzestnego, to właśnie biskup diecezjalny powinien podjąć decyzję, czy należy ustanowić zastępczych (substytutów) rodziców chrzestnych.

Pośrednie wskazanie na taką możliwość w prawie powszechnym, co stanowi możliwość ustanowienia świadka bierzmowania innego niż chrzestny. Szczegółowe rozwiązania pozostawione są jednak regulacjom partykularnym zarezerwowanym przynajmniej dla ordynariusza miejsca.

Bezpośrednie wspomnienie o takiej możliwości w Dekrecie o przysposobieniu powoduje, że nie tylko w tych przypadkach, w których tworzy się nowy akt chrztu, ale w każdym przypadku przysposobienia można ustanowić zastępczych (substytutów) rodziców chrzestnych. W związku z tym, również w innych sytuacjach kiedy nie ma rodziców chrzestnych, kiedy rodzice chrzestni nie mogą pełnić tego zadania, kiedy utracili niezbędne przymioty do wypełniania tego zadania lub prawo zabrania im tego ze względu na zaciągnięte kary kościelne. Można na podstawie podobieństwa kwestii wystąpić

\footnotetext{
32 Por. J.G. Martín, Le norme generali del Codex Iuris Canonici, Venezia 2015

33 Por. Dekret o przysposobieniu, nr 8.
} 155. 
In this case, in any parallel situation where there is a vacancy in the baptismal assignment, it is for the diocesan bishop to decide whether foster (substitute) godparents should be appointed.

An indirect indication of this possibility in common law is the possibility of appointing a witness to Confirmation other than a sponsor. Detailed solutions, however, are left to particularistic regulations reserved at least to the local Ordinary.

The direct reference to this possibility in the Decree on Adoption means that not only in those cases where a new baptismal act is created, but in every case of adoption, substitute godparents can be appointed. Consequently, in situations when there are no godparents, or when the godparents cannot fulfil this assignment, or when they have lost the necessary qualities to fulfil this assignment, or the law forbids them to do so because of ecclesiastical penalties incurred, based on the similarity of the issues, it is possible to request the diocesan bishop to appoint substitute godparents.

However, there remains the question of the resolution of the legal basis. Since for the appointment of foster (substitute) godparents not only in the case of adoption a request has to be made to the diocesan bishop, it has to be said that his decision in an individual case could be taken in the form of a rescript in individual cases, acting on the basis of an interpretation related to the answer to lacuna in the law concerning the vacancy of the baptismal assignment. However, consideration could also be given to the solution of introducing a particularistic law which would respond to the lacuna in the law noted in this article. Such a law would be a legal basis for the entire particularistic Church and would clarify all the cases which could be qualified and which requirements would have to be fulfilled in order for such a procedure of substitution of godparents to take place.

\section{CONCLUSIONS}

In recent times, some parents find it difficult to find even one close family member who meets all the requirements for a sponsor. Sometimes it happens that those chosen as sponsors do not fulfil their 
do biskupa diecezjalnego o wyznaczenie zastępczych (substytutów) rodziców chrzestnych.

Pozostaje jednak kwestia rozwiązania podstawy prawnej. Skoro w celu ustanowienia zastępczych (substytutów) rodziców chrzestnych także poza przypadkiem przysposobienia należy zwrócić się z prośbą do biskupa diecezjalnego, to należy stwierdzić, że jego decyzja w przypadku pojedynczym mogłaby zostać podjęta $\mathrm{w}$ formie reskryptu w pojedynczych przypadkach, działając na podstawie interpretacji związanej z odpowiedzią na lukę prawną dotyczącą wakatu zadania rodzica chrzestnego. Jednakże można byłoby też zastanowić się nad rozwiązaniem wprowadzenia ustawy partykularnej, która byłaby odpowiedzią na zauważoną w tym artykule lukę prawną. Ustawa taka byłaby podstawą prawną dla całego Kościoła partykularnego oraz wyjaśniałaby wszystkie przypadki, które mogłyby zostać zakwalifikowane oraz jakie wymagania należałoby spełnić, aby takie postępowanie ustanowienia substytutów rodziców chrzestnych mogłoby zostać zrealizowane.

\section{ZAKOŃCZENIE}

W ostatnim czasie niektórzy rodzice napotykają trudności ze znalezieniem choćby jednego bliskiego członka rodziny, który spełniałby wszystkie wymagania stawiane wobec kandydatów na rodziców chrzestnych. Czasami bywa tak, że wybrani na rodziców chrzestnych nie wypełniają w ogóle tego zadania. W obliczu nowych wyzwań duszpasterskich, jakim jest zjawisko praktycznego lub nawet formalnego odchodzenia od Kościoła warto jest też przeanalizować ten fakt, wobec przyjętych zadań chrzestnego, a w szczególności dziecka, które traci ową pomoc duchową, która miała mu być dana, aby realizował życie chrześcijańskie i wzrastał w wierze katolickiej.

Kodeks Prawa Kanonicznego chociaż bezpośrednio nie wspomina o możliwości ustanowienia zastępczych (substytutów) rodziców chrzestnych, to jednak pośrednio dopuszcza ustanowienie świadka bierzmowania, który nie jest rodzicem chrzestnym, a w konsekwencji na wytworzenie nowego pokrewieństwa duchowego. Jednakże 
baptismal assignment at all. In the face of new pastoral challenges, which is the phenomenon of practical or even formal departure from the Church, it is also worth analysing this fact, in the light of the assignments accepted by the sponsor and, in particular, of the child, who loses that spiritual help which was supposed to be given to him/her in order to lead a Christian life and grow in the Catholic faith.

Although the Code of Canon Law does not directly mention the possibility of appointing substitute godparents, it does indirectly allow for the appointment of a witness to Confirmation who is not a godparent, and thus for the creation of a new spiritual relationship. However, pastoral prudence suggests that this possibility should not be limited to the celebration of the sacrament of Confirmation. For in situations where the child receives this sacrament relatively far from the age of discernment, it can be said that for a long time he or she is also deprived of spiritual support from the acting godparents.

Therefore, noticing this lacuna in the law regarding the vacancy of the baptismal assignment, it seems necessary to propose a legal solution which would be an attempt to respond to the pastoral situations which have arisen and at the same time would not be in conflict with the norms of common or particularistic law in force. In the author's opinion, the solution presented in this article meets both conditions. 
duszpasterska roztropność podpowiada, że nie należałoby ograniczać takiej możliwości jedynie do sytuacji celebracji sakramentu bierzmowania. Ponieważ w sytuacjach, kiedy dziecko przyjmuje ten sakrament stosunkowo daleko od wieku rozeznania, można stwierdzić, że długo jest pozbawione także wsparcia duchowego ze strony pełniących zadanie chrzestnych.

Dlatego, zauważając ową lukę prawną dotyczącą wakatu zadania rodzica chrzestnego, należało zaproponować rozwiązanie prawne, które będzie próbą odpowiedzi na pojawiające się sytuacje duszpasterskie, a jednocześnie nie będzie w konflikcie z obowiązującymi normami prawa powszechnego, ani partykularnego. W mojej ocenie, zaproponowane w tym artykule rozwiązanie spełnia oba warunki.

\section{Streszczenie}

W wielu przypadkach praktyki duszpasterskiej pojawiają się sytuacje, w których rodzice chrzestni nie mogą, nie chcą pełnić swojego zadania lub nie zostali wyznaczeni przez rodziców lub prawnych opiekunów. W konsekwencji tego dziecko, a nawet dorosły w najbliższym czasie od chrztu nie może otrzymać „pomocy duchowej", którą powinien być rodzic chrzestny wobec swojego chrześniaka.

W przypadku zadania chrzestnego można mówić o pewnego rodzaju analogii do urzędu kościelnego, a w konsekwencji można również stwierdzić istnienie „wakatu” zadania chrzestnego w przy padkach, kiedy nie ma nikogo, kto byłby powołany do udzielenia tej „duchowej pomocy” rodzicom lub prawnym opiekunom.

W rezultacie można mówić o pewnego rodzaju luce prawnej, ponieważ prawo powszechne nie podaje wprost rozwiązania tej kwestii prawnej. Pośrednio jednak można upatrywać rozwiązanie takiej sytuacji w możliwości wyznaczenia świadka bierzmowania, który nie jest chrzestnym. Jednakże to rozwiązanie, zawarte w prawie powszechnym, jest możliwe jedynie w momencie przystępowania do sakramentu bierzmowania. Dlatego można mówić dalej o luce prawnej, ponieważ są inne przypadki, w których ustanowienie zastępczej „pomocy duchowej” świadczonej przez tych, którzy pełnią zadanie rodziców chrzestnych, jest jak najbardziej wskazane. Dlatego w rozwiązaniu tej kwestii należy przywołać prawo partykularne obowiązujące w Polsce, które stosuje się w przypadkach przysposobienia. Tam znajduje się możliwość wyznaczenia zastępczych (substytutów) rodziców chrzestnych. 


\section{Summary}

In many cases of pastoral practice, situations arise in which godparents cannot or do not want to fulfil their assignment or have not been appointed by their parents or legal guardians. As a result, a child, or even an adult, in the near future from baptism cannot receive ,spiritual help", which should be a godparent for his godson.

In the case of a baptismal assignment, one can speak of a kind of analogy with ecclesiastical office, and consequently one can also state the existence of a ,vacancy" in the baptismal assignment in cases where there is no one who would be called to provide this "spiritual help" to the parents or legal guardians.

As a result, one can speak of a kind of legal lack, because common law does not provide a direct solution to this legal issue. Indirectly, however, one can see a solution to this situation in the possibility of appointing a confirmation witness who is not a godfather. However, this solution, enshrined in universal law, is only possible at the time of receiving the sacrament of Confirmation. Therefore, there is a legal lack as there are other cases in which the establishment of a substitute „spiritual assistance" provided by those who act as godparents is most appropriate. Therefore, in resolving this issue, reference should be made to the particularistic law in Poland in force, which applies in cases of adoption. There, it is possible to designate substitute godparents.

Keywords: baptism, sponsor, godparents, appointing foster godparents, confirmation, church office, godparents' assignment

\section{Bibliography}

Arrieta J. I., „,an. 145”, in: Exegetical commentary on the Code of canon law, vol. I, Chicago 2004.

Blanco M., ,can. 872”, in: Exegetical commentary on the Code of canon law, vol. III/1, Chicago 2004.

Chiappetta L., Il Codice di diritto canonico, vol. II, Bologna 2011.

De Paolis V., D’Auria A., Le Norme Generali, Roma 2014.

General Decree of the Polish Bishops' Conference on the Preparation and Modification of the Baptismal Act in relation to Adoption, in Acts of the Polish Bishops' Conference 30(2018) 46-47. 
Słowa klucze: sakrament chrztu, rodzic chrzestny, wyznaczenie zastępczych rodziców chrzestnych, sakrament bierzmowania, urząd kościelny, zadanie chrzestnego

\section{Bibliografia}

Arrieta J. I., „,an. 145”, w: Exegetical commentary on the Code of canon law, vol. I, Chicago 2004.

Blanco M., „,can. 872”, w: Exegetical commentary on the Code of canon law, vol. III/1, Chicago 2004.

Chiappetta L., Il Codice di diritto canonico, vol. II, Bologna 2011.

De Paolis V., D'Auria A., Le Norme Generali, Roma 2014.

Dekret ogólny Konferencji Episkopatu Polski dotyczacy sporządzenia i modyfikacji aktu chrztu w zwiazku z przysposobieniem, w: Akta Konferencji Episkopatu Polski 30(2018) 46-47.

Frank E., I sacramenti dell'Iniziazione, della Penitenza e dell'Unzione degli infermi, Roma 2012.

Hipolit Rzymski, Tradycja Apostolska, w: Paprocki Henryk, «Hipolita Rzymskiego Tradycja Apostolska. Wstęp, przekład komentarz», Studia Theologica Varsaviensa, 14/1 (1976) 145-169.

Katechizm Kościoła Katolickiego, Poznań 1994.

Komisja Wychowania Katolickiego, „Wskazania Konferencji Episkopatu Polski dotyczące przygotowania do przyjęcia sakramentu bierzmowania", (14 marca 2017 r.), nr 17, w: Akta Konferencji Episkopatu Polski 29 (2017) 65-70.

Konstytucje Apostolskie, A. Baron; H. Pietras (red.), Kraków 2007.

Martín J. G., Le norme generali del Codex Iuris Canonici, Venezia $2015^{6}$.

Obrzędy chrześcijańskiego wtajemniczenia dorostych dostosowane do zwyczajów diecezji polskich, Katowice 1998.

Obrzędy chrztu dzieci dostosowane do zwyczajów diecezji polskich, wyd. 3, Katowice 2007.

Papieska Rada do Spraw Jedności Chrześcijan, Dyrektorium ekumeniczne, 25 marca 1993 r., w: AAS 85 (1993) 1039-1119. Polski przekład: Ut unum. Dokumenty Kościoła katolickiego na temat ekumenizmu 1982-1998, S.C. Napiórkowski (red.), Lublin: Towarzystwo Naukowe Katolickiego Uniwersytetu Lubelskiego.

Perlasca A., „La figura e il ruolo dei padrini nei sacramenti dell'iniziazione cristiana", w: Quando si diventa cristiani. I sacramenti dell 'iniziazione: indicazioni canoniche e pastorali, G. Trevisan (ed.), Milano 2003.

Pighin B., Diritto sacramentale canonico, Venezia 2016. 
Frank E., I sacramenti dell'Iniziazione, della Penitenza e dell'Unzione degli infermi, Roma 2012.

Hippolytus of Rome, Apostolic Tradition, in: Paprocki Henryk, „The Apostolic Tradition of Hippolytus of Rome. Introduction, Translation and Commentary", Studia Theologica Varsaviensa, 14/1 (1976) 145-169.

Catechism of the Catholic Church, Poznan 1994.

Commission for Catholic Education, „Guidelines of the Polish Bishops' Conference on Preparation for the Reception of the Sacrament of Confirmation," (March 14, 2017), no. 17, in Acts of the Polish Bishops' Conference 29 (2017) 65-70. Apostolic Constitutions, A. Baron; H. Pietras (ed.), Kraków 2007.

Martín J. G., Le norme generali del Codex Iuris Canonici, Venezia $2015^{6}$.

Rites of Christian Initiation of Adults Adapted to the Customs of the Dioceses of Poland, Katowice 1998.

Rites of Baptism of Children Adapted to the Customs of the Dioceses of Poland, 3rd edition, Katowice 2007.

Pontifical Council for Christian Unity, Ecumenical Directory, 25 March 1993, in: AAS 85 (1993) 1039-1119. Polish translation: Ut unum. Dokumenty Kościoła katolickiego na temat ekumenizmu 1982-1998, S.C. Napiórkowski (ed.), Lublin: Scientific Society of the Catholic University of Lublin.

Perlasca A., „La figura e il ruolo dei padrini nei sacramenti dell'iniziazione cristiana", in: Quando si diventa cristiani. I sacramenti dell'iniziazione: indicazioni canoniche e pastorali, G. Trevisan (ed.), Milano 2003.

Pighin B., Diritto sacramentale canonico, Venezia 2016.

Pinto P., Commento al Codice dei Canoni delle Chiese Orientali, Città del Vaticano 2001.

Plezia M., Latin-Polish Dictionary, vol. V, Warsaw 1999.

Rincón-Pérez T., La liturgia e i sacramenti nel diritto della chiesa, Roma 2014.

Tertullian, De baptismo, (XVIII,4), in: Tertullien, Traité du baptême, Sources Chrétiennes, Paris 1952. 
Pinto P., Commento al Codice dei Canoni delle Chiese Orientali, Città del Vaticano 2001.

Plezia M., Stownik tacińsko-polski, t. V, Warszawa 1999.

Rincón-Pérez T., La liturgia e i sacramenti nel diritto della chiesa, Roma 2014.

Tertullian, De baptismo, (XVIII,4), w: Tertullien, Traité du baptême, Sources Chrétiennes, Paryż 1952. 